\title{
Effects of surficial condition and rainfall intensity on runoff in a loess hilly area, China
}

\author{
Wei Wei ${ }^{a}$, Fuyan Jia ${ }^{a, b}$, Lei Yang ${ }^{a}$, Liding Chen ${ }^{\mathrm{a}, *}$, Handan Zhang ${ }^{\mathrm{a}, \mathrm{b}}$, Yang Yu ${ }^{\mathrm{a}}$ \\ a State Key Laboratory of Urban and Regional Ecology, Research Center for Eco-Environmental Sciences, Chinese Academy of Sciences, Beijing 100085, China \\ ${ }^{\mathrm{b}}$ University of Chinese Academy of Sciences, Beijing 100049, China
}

\section{A R T I C L E I N F O}

\section{Article history:}

Received 13 January 2014

Received in revised form 1 March 2014

Accepted 7 March 2014

Available online 20 March 2014

This manuscript was handled by

Konstantine P. Georgakakos, Editor-in-Chief, with the assistance of Ellen Wohl, Associate Editor

\section{Keywords:}

Runoff

Rainfall simulation

Water loss

Plant species

Vegetation position

Surface cover

\begin{abstract}
S U M M A R Y
Knowledge of the so-called "source-sink" pattern of surface runoff is important for soil conservation, water resources management and vegetation restoration in the dry-land ecosystems. Micro-runoff plot and rainfall simulation are effective tools in quick understanding the relations between land surface and runoff dynamics. This study made full use of these tools to examine the effect of various factors (plant species, surface cover, vegetation distribution) on runoff generation in the semiarid loess hilly area of China. Two major simulated rainfall intensities $\left(52 \mathrm{~mm} \mathrm{~h}^{-1}\right.$ and $28 \mathrm{~mm} \mathrm{~h}^{-1}$ ) were designed and conducted, which can represent heavy rainstorms and moderate rainfalls in the local region, respectively. Results showed that the responses of runoff generation and dynamics were far more sensitive to high-intensity rainfalls. Rainfall events with only 1.8 times an increase in intensity and $16 \%$ decrease in duration caused a sharp increase in total discharge (13.96 times), runoff depth (16.33 times), mean flow velocity (12.17 times), peak flow velocity (9.34 times) and runoff coefficient (9.23 times), respectively. The time to runoff generation however, was shortened by $70 \%$, which raised the alarm to caution against the risks of hydrological disasters induced by potential rainfall variation in the context of climatic change. More importantly, different plant species and surface cover play various roles in runoff generation and processes. Due to the difference in plant morphology and effective surface cover, runoff delay, total discharge retention and peak-flow reduction with shrubs (seabuckthorn) were more effective than those with secondary natural grass, followed by biological crust and bare soil. Notably, the specific positions of shrub species along the slope affects the time to runoff, specific flow process and total volume significantly. Shrubs in the lower positions acted as more powerful buffers in preventing runoff generation and surface water loss. Such findings can provide important references for runoff control, water conservation and ecosystem restoration regarding plant selection and vegetative collocation in practice in the arid and semiarid environments.
\end{abstract}

() 2014 Elsevier B.V. All rights reserved.

\section{Introduction}

Water scarcity is the greatest problem in semiarid and arid regions such as the Loess Plateau, the Mediterranean and other similar areas around the world (Chen et al., 2007; Wang et al., 2011; Maetens et al., 2012). In the context of human accelerated global warming, many dry-land areas are suffering from warmer and drier climates (Richard, 2007), which further worsen the status of water-carbon contradiction, increase the difficulties of plant growth and threaten the sustainability of ecosystem restoration (Putten et al., 2013). More alarming is an increasing trend in destructive rainstorms with higher intensity and more severe erosivity, which may possibly continue on large scale, consequently

\footnotetext{
* Corresponding author. Tel./fax: +86 1062943840.

E-mail addresses: weiwei@rcees.ac.cn (W. Wei), liding@rcees.ac.cn (L. Chen).
}

increasing the potential risks of water loss in many fragile and mountainous regions (Weltzin et al., 2003; Sun et al., 2002; Zhao et al., 2009). Conserving scarce water resources in situ for better plant utilization thus becomes extremely important in such thirsty regions (Yang et al., 2012). Runoff and water flow along the hillslope conditions, on the other hand, has long been blamed for aggravating water shortage stress, causing soil nutrient loss and hampering the process of vegetation restoration (Sinoga et al., 2010). Consequently, a deep understanding of the mechanism regarding runoff performance and finding more valuable solutions to control runoff loss are significant for vegetation restoration and ecological rehabilitation, especially against the background of climatic change.

In general, runoff processes are characterized by high spatiotemporal variability in arid and semiarid ecosystems, resulting from the interaction among different environmental factors at 
specific scales (Imeson and Prinsen, 2004; Sinoga et al., 2010). There is no-doubt that the dynamics of rainfall features such as intensity and depth contribute to runoff generation and hydrological variation (Wei et al., 2007, 2009; Shi et al., 2010, 2012). The deep rainfall-runoff relation however, is also largely regulated by such surface conditions as plant species, soil crusts, surface cover, antecedent soil moisture, vegetation buffer strips and specific positions (Sun et al., 2000; Wei et al., 2007; Sinoga et al., 2010; Chamizo et al., 2012), which makes the interactions among them uncertain over time and space. Consequently, the related factors and runoff generation processes were quite complex and difficult to quantify. For example, studies have confirmed that vegetation cover is a key factor influencing runoff generation (Cantón et al., 2011), but how the source and sink of runoff transfers with plant morphology and its spatial location remains unclear (Xu et al., 2008), particularly when experiencing stochastic rainfall pulses. No sufficient information was provided for selecting suitable plant species in terms of plant morphology and spatial distribution for runoff reduction and vegetation restoration in water-limited environments (de Baets et al., 2007; Xu et al., 2009). Moreover, in such arid and semiarid zones, local hill-slopes are always characterized by spatially discontinuous vegetation, which reflects the limited supply of soil water and nutrients. The specific plant species and vegetation position can influence the location of runoff "source-sink" areas markedly (Bochet et al., 1998; Ma et al., 2013). So far, few studies have actually linked spatial vegetation position to geo-hydrological processes (Imeson and Prinsen, 2004; Mayor et al., 2011). Clarifying how plant morphology and vegetation distribution reflect and respond to rainfall pulses is thus of great value. Although abundant studies regarding rainfall-runoff relations in different climatic zones were conducted across multiple scales, it still lacks a comprehensive understanding about the mechanism of runoff dynamics within different environments (Xiao et al., 2011; Chamizo et al., 2012; Shi et al., 2013).

Unfortunately, due to water limitation and infrequent rainfalls in dry-lands, getting enough field data is always restricted by the fact that there are few naturally occurring runoff events, which hinders the progress in basic research regarding this topic. Rainfall simulation experiments, however, can overcome this drawback and provide huge amounts of data for model calibration and mechanism exploration within short periods, only because such experiments are easily conducted in the fields (Shi et al., 2012; Huang et al., 2013). Studies across different regions have pointed out that rainfall simulation by portable simulator at a fine scale is a powerful tool in surface hydrological studies (Cerdà, 1998; Abudi et al., 2012). Furthermore, rainfall simulators can create different scenarios regarding variations in rainfall variables, helping to ascertain runoff response to rainfall and soil surface conditions. Since the end of 1930s, more than 100 rainfall simulators with less than $5 \mathrm{~m}^{2}$ plot areas as the land surface were developed (Pérez-Latorre et al., 2010). So far, such fine-scale studies are more focused on the semiarid Mediterranean region in Europe and other areas such as the dry-hot valleys in southwest China (Borin et al., 2005; Xu et al., 2008, 2009). Systematic research regarding the role of plant species and vegetation distribution in runoff at micro-scales was rarely conducted in the Loess Plateau of China.

The semiarid Loess Plateau in China, which covers 0.64 million $\mathrm{km}^{2}$ of the land territory, has long been criticized as one of the most degraded regions around the world due to its severe droughts and fragile ecosystem (Chen et al., 2007; Wang et al., 2011; Yang et al., 2012). Recent studies declared that water resources may become more inadequate in many areas of the plateau due to social development and global warming (Li et al., 2009; Wang et al., 2011). In general, precipitation has been detected to decline while temperature and evapotranspiration have increased, although such variations remain across time and space.
Meanwhile, heavy rainstorms with higher intensities in this region may possibly increase by about $8-35 \%$ (Zhang and Liu, 2005), which can further raise the sensitivity of land surface to rainfall pulses and thus cause higher risks of runoff loss. Although we know that plant species and vegetation patterns may play a key role in water dynamics, it is still unclear which species and what kinds of spatial patterns are more effective in runoff control. As a consequence, conserving limited water resources through enhancing infiltration in situ and reducing overland-flow at slopes becomes more challenging. Facing these issues, fine-scale studies, rather than coarse scale, can focus on specific hydrological processes and may help to answer this question (Bochet et al., 1998; Ellis et al., 2006; Chamizo et al., 2012).

In this study, 16 micro-plots were established in the growing season of 2010, in Dingxi, a semiarid loess hilly area of China. Rainfall simulation experiments were implemented for analyzing different land surface conditions (plant species, surface cover and vegetation distribution) and rainfall characteristics on runoff generation and water discharge dynamics. Specifically, three major sub-objectives were expected to be achieved: (1) to analyze the response of runoff generation, surface flow rates and total runoff reduction to two major simulated rainfalls, (2) to determine how different runoff indicators respond to plant species and surface coverage, and (3) to analyze the role of plant position and spatial vegetation distribution on runoff dynamics.

\section{Materials and method}

\subsection{Study area}

Our rainfall-simulation experiments were designed and conducted in the Anjiapo catchment $\left(35^{\circ} 33^{\prime}-35^{\circ} 35^{\prime} \mathrm{N}, 104^{\circ} 38^{\prime}-\right.$ $104^{\circ} 41^{\prime} \mathrm{E}$ ) in Dingxi county of Gansu province, in the western part of the Chinese Loess Plateau (Fig. 1). In this rain-fed and semiarid catchment, a field meteorological station was established in 1985, which belongs to the Dingxi Institute of Soil and Water Conservation. According to the water deficit index (WDI) and the aridity index (ARI), this region is located in a semiarid climatic zone and is dominated by the warm-humid summers and cold-dry winters. The mean annual precipitation (based on local recorded data from 1956 to 2010) is $421 \mathrm{~mm} /$ year, of which about 78\% total rain falls during the growing season, i.e., from May to September (Wei et al., 2009). The mean annual pan evaporation however, can reach about $1515 \mathrm{~mm}$. According to over 50 years (1954-2004) of monitored data in the field station, the precipitation experienced a decreasing trend while the temperature continued to increase during the past decades, which means that the local climate is becoming drier and warmer. Such a situation may further aggregate water pressure and do harm to vegetation restoration in this region.

Local soil is developed from loess material, with a mean soil depth ranging from 40 to $60 \mathrm{~m}$. The deepest soil layer in some areas, however, can reach and even exceed more than $100 \mathrm{~m}$. According to the soil classification system, the soil in this area is dominated by calcic Cambisol (FAO-UNESCO, 1974) with a clay content of $33-42 \%$, organic matter of $4-13 \mathrm{~g} / \mathrm{kg}$, and a bulk density from 1.09 to $1.36 \mathrm{~g} / \mathrm{cm}^{3}$ within a $2 \mathrm{~m}$ soil depth (Chen et al., 2007). No available groundwater can be used for vegetation growth and restoration, mainly due to deep loess soil and severe drought. Limited annual rainfall is thus the only usable water resource for plants. Deep percolation can be neglected in most cases (Wang et al., 2011).

In general, the local climate is more suitable for shrub and grass species to grow, although some tree species (e.g. Chinese pine, Chinese arborvitae, poplar and willow) were planted widely in the 


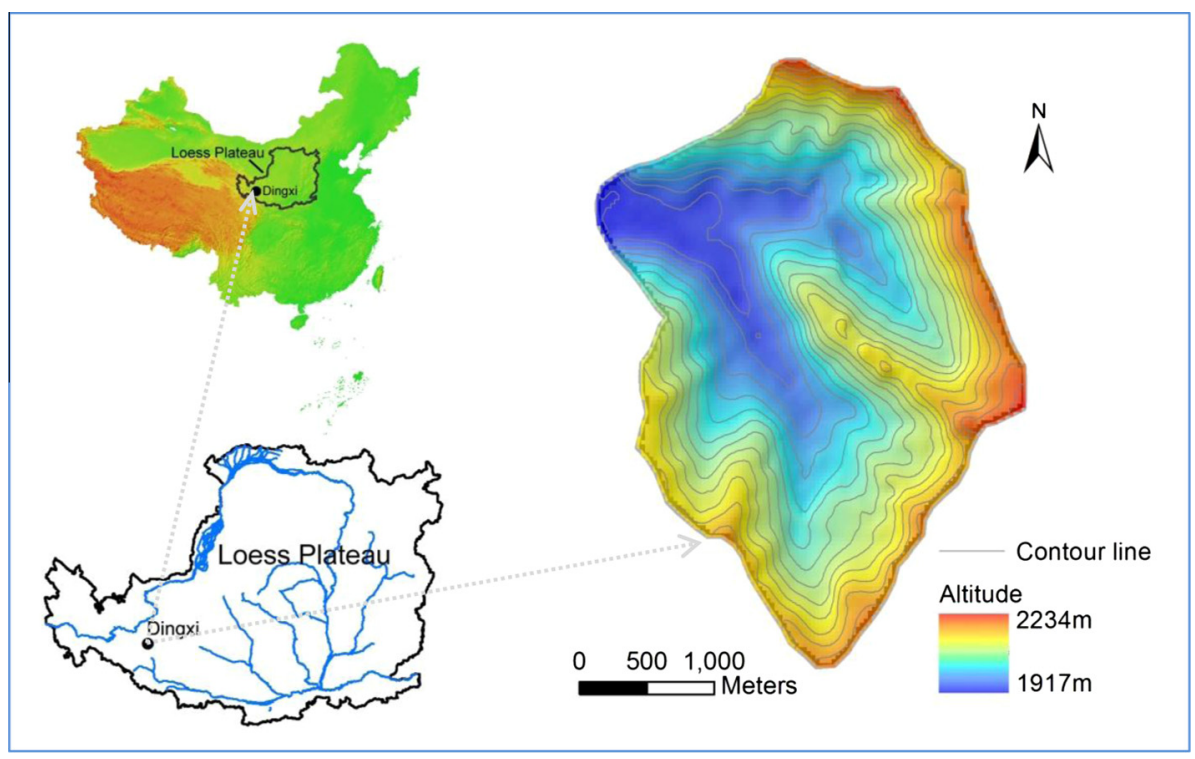

Fig. 1. The geographical location of the Anjiagou catchment.

watershed during the past several decades (Chen et al., 2007; Wei et al., 2009; Yang et al., 2012). In recent years, due to the implementation of "grain-for-green" (the conversion of sloping cropland to forestland or grassland), "natural forest protection," labor service exports and other important projects targeting enriching local farmers and protecting the environment, steeping farmlands were largely forbidden and returned to forests and shrubs, or abandoned for natural succession. Soil biological crusts, being as key components of the surface soil in dry-land ecosystems, are also highly developed at large scales. Such microorganisms (e.g. mosses and lichens in most cases) are called "biological carpet" by local farmers, which can play important roles in soil carbon accumulation and erosion control in the arid and semiarid geographical zones (Chamizo et al., 2012; Rodríguez-Caballero et al., 2012). The majority of the remainders of vegetation are secondary shrubs, grasses and some other artificial vegetation types. The dominant introduced tree species are: Chinese pine (Pinus tabuliformis Carr.), Chinese arborvitae (Platycladus orientalis L.) and apricot (Prunus armeniaca L.). These tree species however, are more suitable for growing in lower positions of the hill-slope with relatively higher soil moisture and nutrients. Shrub species are mainly seabuckthorn (Hippophae rhamnoides L.) and pea shrub (Caragana kansuensis Pojark.), whereas artificial and natural grass species are mainly alfalfa (Medicago sativa L.), sainfoin (Onobrychis vichfolia Scop.), common leymus (Leymus secalinus T.), solidleaf bluegrass (Poa stereophylla K.) and bunge needlegrass (Stipa bungeana Trin.).

\subsection{Field experimental design}

In the early spring of 2010 , sixteen experimental mini-plots in the Anjiapo catchment were established in a gentle northwest-facing hillslope near the field station of the Dingxi Institute of Soil and Water Conservation (Fig. 1 and Table 1). Before the plots were constructed, the selected site was covered by secondary natural grass and sparse seabuckthorn (Hippophae rhamnoides L.) shrubs which grew naturally without any human management. The grass species has grown for more than 20 years, while seabuckthorn began to invade into the hillslope since 2008 , possibly due to the settlements of human or bird carried seeds. Steel material was selected and used as the basic material for each micro-plot construction. The thickness of the steel was $5 \mathrm{~mm}$ with a height of $50 \mathrm{~cm}$. A $20 \mathrm{~cm}$ depth was embedded into the soil, leaving the remaining $30 \mathrm{~cm}$ height above ground as the border for preventing runoff loss. A discharge ditch was created at the top of each plot for controlling runoff and sediment from the upper slope. At the base of each micro-plot, a marked V-flume and a plastic drum were installed at the outlet of each plot for runoff collection. Furthermore, in order to minimize human disturbance to the inside areas of the plots, the "least perturbations method" plot-setting procedure was created and conducted during the whole installation process (Fig. 2). This method ensured that rainfall-simulation experiments could be done immediately after the plots were established.

In total, four major land surface cover types were involved, which include shrub (seabuckthorn, Hippophae rhamnoides L.), grass (bunge needle grass, Stipa bungeana Trin.) and biological soil crust (BSCs) as well as bare soil (Fig. 3). Meanwhile, three types of shrub distributions were also designed for further detection and analysis, i.e., shrub in the upper side of the plot (SH-U), shrub in the middle side of the plot (SH-M) and shrub in the lower part of the plot $(\mathrm{SH}-\mathrm{L})$. Such treatments were used for comparing the influence of the spatial positioning of plant species on runoff generation and surface water distribution. For grass, bare soil and BSCs plots, the covered area for each runoff plot was $1.59 \mathrm{~m}^{2}$. For shrub plots, each projected plot-area was $2.55 \mathrm{~m}^{2}$ (Table 1 and Fig. 3 ).

\subsection{Rainfall simulation and data collection}

In this study, a portable rainfall simulator, described by Luk et al. (1986), was used with a SPRACO cone jet nozzle, mounted $4.57 \mathrm{~m}$ above the soil surface (Fig. 3). Due to the field convenience and data reliability of this method, it has been used extensively in surface hydrology research by many scholars (Shi et al., 2010, 2012). Specifically, the median volume of rain-drop size obtained by this simulator was $2.4 \mathrm{~mm}$, and the uniformity coefficient of rainfall reached 0.897 in most cases.

Windless days were selected for conducting the rainfall simulations in the field. One rainfall simulator was used to obtain lowintensity rainfalls (LIRs), while two rainfall simulators were used together for obtaining high-intensity rainfalls (HIRs) (Fig. 3a and b). During each experiment, surface runoff was collected at $3 \mathrm{~min}$ intervals and the total runoff volume was measured during each simulated rainfall event. In order to save water, most of the simulated rainfall experiments were performed within $45 \mathrm{~min}$. In general, surface runoff ceased immediately after each rainfall 
Table 1

Mean characteristic of plant species and surface cover in different micro-plots.

\begin{tabular}{|c|c|c|c|c|c|c|c|c|}
\hline Surface cover & Total plant species & Dominated plant species & Height $(\mathrm{cm})$ & Abundance & Coverage (\%) & Evenness & Total coverage (\%) & Slope gradient (\%) \\
\hline \multirow[t]{4}{*}{ Grass } & \multirow[t]{4}{*}{14} & Common leymus & 45 & 5 & 29 & 2 & \multirow[t]{4}{*}{69} & \multirow[t]{4}{*}{12} \\
\hline & & Solidleaf bluegrass & 46 & 5 & 28 & 2 & & \\
\hline & & Capillary wormwood & 32 & 5 & 16 & 2 & & \\
\hline & & Bryophytes & N.A. & N.A. & 81 & N.A. & & \\
\hline \multirow[t]{4}{*}{$\mathrm{SH}-\mathrm{U}$} & \multirow[t]{4}{*}{10} & Seabuckthorn & 87 & 1 & 41 & 2 & \multirow[t]{4}{*}{73} & \multirow[t]{4}{*}{13} \\
\hline & & Capillary wormwood & 34 & 3 & 19 & 2 & & \\
\hline & & Common leymus & 51 & 3 & 11 & 2 & & \\
\hline & & Bryophytes & N.A. & N.A. & 66 & N.A. & & \\
\hline \multirow[t]{4}{*}{ SH-M } & \multirow[t]{4}{*}{14} & Seabuckthorn & 112 & 1 & 73 & 2 & \multirow[t]{4}{*}{86} & \multirow[t]{4}{*}{11} \\
\hline & & Common leymus & 47 & 3 & 32 & 2 & & \\
\hline & & Solidleaf bluegrass & 39 & 2 & 6 & 2 & & \\
\hline & & Bryophytes & N.A. & 60 & N.A. & N.A. & & \\
\hline \multirow[t]{4}{*}{ SH-L } & \multirow[t]{4}{*}{12} & Seabuckthorn & 86 & 2 & 45 & 2 & \multirow[t]{4}{*}{72} & \multirow[t]{4}{*}{13} \\
\hline & & Common leymus & 52 & 3 & 27 & 2 & & \\
\hline & & Capillary wormwood & 32 & 3 & 13 & 2 & & \\
\hline & & Bryophytes & N.A. & N.A. & 56 & N.A. & & \\
\hline BSCs & 1 & Bryophytes & N.A. & N.A. & 67 & N.A. & 67 & 12 \\
\hline Bare soil & 0 & N.A. & N.A. & N.A. & N.A. & N.A. & 0 & 12 \\
\hline
\end{tabular}

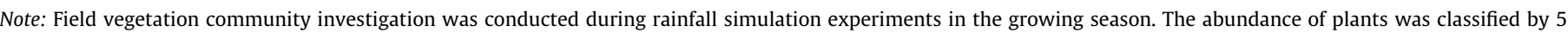
levels; the evenness was defined as two classes ( 1 for uneven, and 2 for evenness). N.A. refers to no available data.

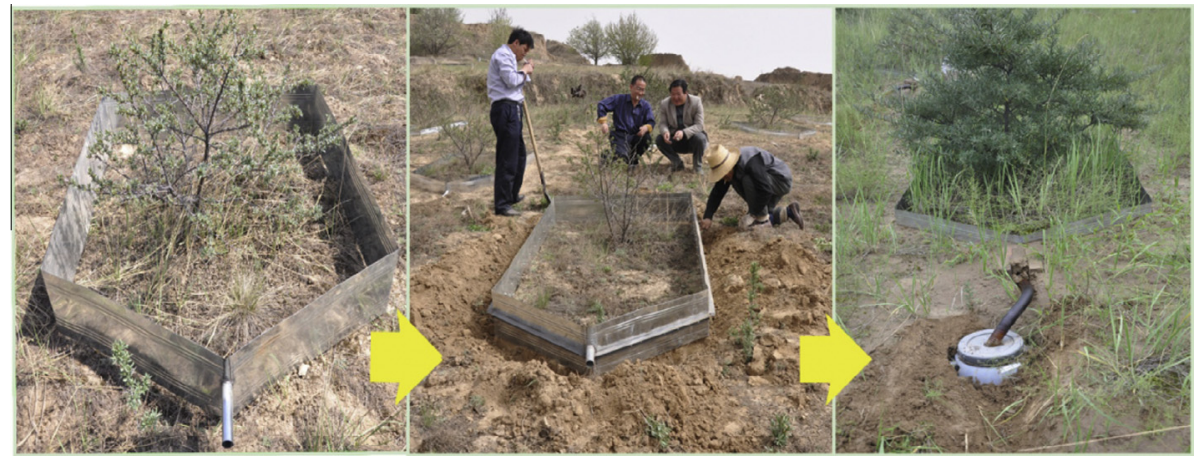

Fig. 2. The sketch-map regarding the specific micro-plot construction procedure.

simulation was finished, and this is mainly because of the initial dry soil condition and weak water-flow velocity. Basic rainfall variables and surface hydrological indicators such as rain depth, duration, antecedent soil moisture, total runoff discharge and time to runoff generation were all taken into consideration.

Among these hydrological variables, rainfall depth and duration was measured and recorded by a traditional $\mathrm{SM}_{1}$ pluviometer and a $\mathrm{SJ}_{1}$ auto-siphon udometer. Initial soil water content was measured by a portable TDR (Time Domain Reflectometer) instrument before and after each field experiment. On the basis of the above hydrological data, other selected variables, including rainfall intensity, runoff depth, mean/peak flow velocity, and runoff coefficient (RC) were all calculated and used for further analysis. Herein, the final consequence of runoff was represented by total runoff discharge and runoff depth. The other runoff variables refer to the detailed runoff dynamics and specific processes.

$\mathrm{PSF}_{i j}=\frac{1}{i} \sum_{i=1}^{i}\left(\mathrm{PFV}_{i j} / \mathrm{MFV}_{i j}\right)$

where $i$ is the number of simulated rainfall events, and $j$ is the number the underlying surface types. $\mathrm{PSF}_{i j}, \mathrm{PFV}_{i j}$ and $\mathrm{MFV}_{i j}$ is the peak shape factor, peak flow velocity and mean flow velocity, respectively, when the $i$ time simulated rainfall was conducted at $j$ site.

$\mathrm{RUD}_{i j}=\frac{1}{i} \sum_{i=1}^{i}\left(\mathrm{TRD}_{i j} / \mathrm{MPA}_{j}\right)$ where RUD ${ }_{i j}$ and $\mathrm{TRD}_{i j}$ represents runoff depth and total runoff discharge, respectively, when the $i$ time simulated rainfall was conducted at $j$ site. $\mathrm{MPA}_{j}$ is the measured plot area of $j$ site.

$\mathrm{RC}_{i j}=\frac{1}{i} \sum_{i=1}^{i}\left(\mathrm{RUD}_{i j} / \mathrm{SRD}_{i j}\right)$

where $\mathrm{RC}_{i j}$ and $\mathrm{RD}_{i j}$ represent runoff coefficient and simulated rainfall depth when the $i$ time simulated rainfall was conducted at $j$ site.

\subsection{Statistical analysis}

Descriptive statistical analysis was used for detecting the general features of simulated rainfall and related runoff characteristics. The mean value and standard deviation of each rainfall variable and runoff indicator under two major rain-intensities were quantified for further analysis. The above mentioned statistical analyses were conducted in the SPSS16.0 for Windows. In addition, histograms and line charts which depicted the features of hydrological responses were all drawn in the Excel 2007.

\section{Results}

\subsection{Simulated rainfall and related runoff characteristics}

In total, 126 rainfall simulations (24 times for grass and shrub plots, 16 times for biological crust plots and 14 times for bare land) 


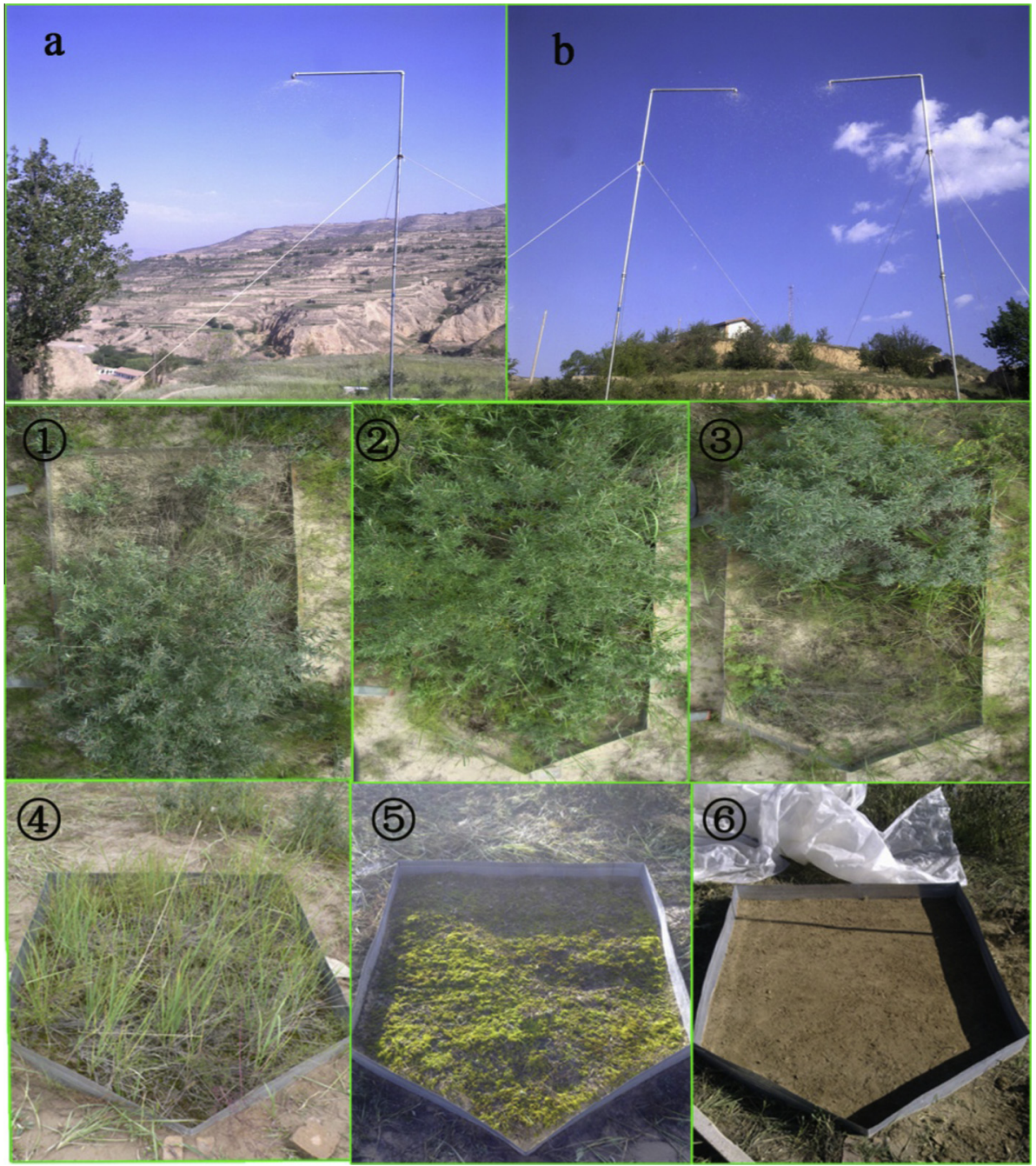

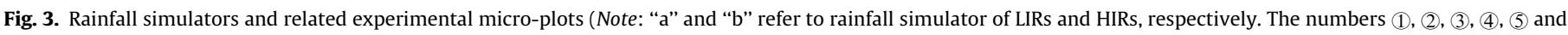
(6) represent $\mathrm{SH}-\mathrm{L}, \mathrm{SH}-\mathrm{M}, \mathrm{SH}-\mathrm{U}$, grass, BSCs and bare soil, respectively).

were conducted during the growing season (from July to September) of 2011. Features of the simulated rainfall events and related runoff responses were captured (Table 2). Two major rainfallintensity events (LRIs and HIRs) were gathered by using one or two rainfall simulators together in the same plots (Fig. 3), respectively. In general, high-intensity rainfalls (HIRs) were recorded with a mean intensity value of $52 \mathrm{~mm} \mathrm{~h}^{-1}$, ranged from $42 \mathrm{~mm} \mathrm{~h}^{-1}$ to $58 \mathrm{~mm} \mathrm{~h}^{-1}$, respectively. The recorded rainfall depth and dura- tion, on the other hand, ranges from 33.2 to $50.7 \mathrm{~mm}$ and from $42.4 \mathrm{~min}$ to $63.3 \mathrm{~min}$, respectively. For the low-intensity rainfall events (LIRs), the recorded rainfall depth and duration varied from $9.9 \mathrm{~mm}$ to $57.6 \mathrm{~mm}$ and from $19.7 \mathrm{~min}$ to $122 \mathrm{~min}$, with a mean value of $26.5 \mathrm{~min}$ and $57.4 \mathrm{~min}$, respectively. The calculated intensities of such rainfalls were captured with a mean value of $28 \mathrm{~mm} \mathrm{~h}^{-1}$, ranging from $20 \mathrm{~mm} \mathrm{~h}^{-1}$ to $37 \mathrm{~mm} \mathrm{~h}^{-1}$. According to a comparison with local measured precipitation data from the field

Table 2

Two major simulated rainfalls and related characteristics of surface runoff response.

\begin{tabular}{|c|c|c|c|c|c|}
\hline \multirow[t]{2}{*}{ Rainfall/runoff indicators } & \multicolumn{2}{|c|}{ High-intensity rainfalls (HIRs) } & \multicolumn{2}{|c|}{ Low-intensity rainfalls (LIRs) } & \multirow[t]{2}{*}{ HIRs/LIRs } \\
\hline & Mean & S.D. & Mean & S.D. & \\
\hline Rain depth (mm) & 41.3 & 3.738 & 26.5 & 8.605 & 1.56 \\
\hline Duration (min) & 48.2 & 2.987 & 57.4 & 20.147 & 0.84 \\
\hline Intensity (mm/h) & 51.5 & 4.023 & 28.3 & 4.747 & 1.82 \\
\hline ASM (\%) & 19.2 & 7.94 & 18.5 & 5.024 & 1.04 \\
\hline Time to runoff (s) & 191.8 & 161.469 & 639.4 & 268.254 & 0.30 \\
\hline Total discharge $(\mathrm{ml})$ & 8134.1 & 7569.191 & 582.5 & 569.436 & 13.96 \\
\hline $\operatorname{MFR}(\mathrm{ml} / \mathrm{min})$ & 176.4 & 169.078 & 14.5 & 15.876 & 12.17 \\
\hline $\mathrm{PFR}(\mathrm{ml} / \mathrm{min})$ & 219.4 & 205.013 & 23.5 & 24.485 & 9.34 \\
\hline Runoff depth (mm) & 4.9 & 5.156 & 0.3 & 0.351 & 16.33 \\
\hline $\mathrm{RC}(\%)$ & 12 & 12.195 & 1.3 & 1.459 & 9.23 \\
\hline
\end{tabular}

Note: The abbreviations ASM, MFR, PFR and RC refer to antecedent soil moisture, mean flow rate, peak flow rate and runoff coefficient, respectively. 
station, the two classified rainfall types can be defined as moderate-intensity events and high-intensity storms, both of which are prone to cause severe runoff and water loss in local sloping conditions in most cases.

According to the results shown in Table 2, surface runoff varied highly within the two mentioned rainfall types. The mean value of time to runoff generation was $192 \mathrm{~s}$ under the HIRs, while the related time value for runoff starting became $639 \mathrm{~s}$ under the LIRs, which is 3.3 times more lag than that under HIRs. Meanwhile, other key runoff indicators such as total discharge, mean flow velocity, peak flow velocity, runoff depth and runoff coefficient were all far higher under HIRs than those under LIRs, with a mean value of $8.13 \mathrm{~L}, 176 \mathrm{ml} / \mathrm{min}, 219 \mathrm{ml} / \mathrm{min}, 4.9 \mathrm{~mm}$ and $12 \%$ in this study, respectively. Furthermore, according to the value of HIR/ LIR shown in Table 2, the hydrological consequences between high-intensity and low-intensity rainfalls became more distinct. Specifically, an increase in less than 2 times the rainfall intensity has caused about 14 times the increase of total discharge; 12 times the increases of MFR and 9 times of PFR; 16 times of runoff depth; and more than 9 times the increase of RC.

\subsection{Runoff dynamics under different plant species and soil surface cover}

In general, our study found that runoff under different plant species and soil surface cover varied highly both under HIRs and LIRs (Fig. 4). Total discharge, mean flow velocity, peak flow velocity, runoff depth and runoff coefficient were all in the decreasing order of bare soil > BSCs > grass > shrub, both under HIRs and LIRs conditions. Meanwhile, the related values of runoff indicators under bare soil and BSCs were far higher than those under grass and shrub species, regardless of the rainfall intensities. Moreover, shrub plant species (seabuck thorn, Hippophae rhamnoides L.), rather than grass species, are more effective in reducing total discharge and specific water processes such as peak flow rate. The time-to-runoff generation, however, responded differently across various surface soil features and plant species. Namely, biological soil crust is mostly prone to generating runoff, followed by bare soil surface and grass, while the seabuckthorn shrub species was observed to play the best role in delaying the occurring time of runoff.

Meanwhile, the specific processes of runoff rate and accumulative runoff discharge at each 3 min time interval were also captured (Fig. 5). It can be found that distinct response of runoff processes appeared among different plant species and soil surface cover. The runoff rate increased sharply under bare soil conditions during the whole simulation time. For BSCs, although the changing trend of runoff rate was less than that of bare soil, also increased far more quickly than grass and shrub during the first several minutes. A 9-12 min after runoff generation, however, the flow velocity decreased and stayed at a relatively stable level almost throughout the remaining phases. Compared with bare soil and BSCs, the response of runoff rate under shrub and grass species seemed to be less sensitive to rainfall. Only at the first 3-6 min after runoff starting, a small increasing trend of runoff rate appeared, and then kept a very stable level. In general, for the four total surface cover types, runoff rate and accumulated runoff discharge were both in the same decreasing order of bare soil $>$ BSCs $>$ grass $>$ shrub. No similar values of runoff rates among the four surface covers appeared at any time intervals.

\subsection{Runoff responses to different vegetation distribution and slope position}

Our study found that the specific position of shrub species in the plots played an important role in altering runoff consequences
(Fig. 6). Under both HIRs and LIRs conditions, the total discharge, runoff depth, runoff coefficient, mean flow velocity, and peak flow velocity all captured the highest value when shrub was located in the upper area of the plots (SH-U). The runoff coefficient, which refers to the ratio of runoff depth to total rainfall depth, also followed the same dynamic rule with other key runoff variables. Shrub in the middle area of the plot ( $\mathrm{SH}-\mathrm{M})$ was much better at controlling runoff and reserve surface water than shrub in the upper areas (SH-U). The lowest values of runoff processes and volume were captured when shrub was located in the lower part of the plots (SH-L). Conversely, the time to runoff generation was found in the order of ST-L $>$ ST-M $>$ ST-U. No runoff occurred under ST-L under LTRs conditions, and thus there were no available data to show the time to runoff generation (Fig. 6). This consequence, however, re-confirmed the powerful buffering role of SH-L on runoff reduction.

Meanwhile, the specific process of runoff rate and accumulative volume at 3 min time intervals were detected and analyzed (Fig. 7). In general, the two indicators both declined in the following order of $\mathrm{SH}-\mathrm{L}<\mathrm{SH}-\mathrm{M}<\mathrm{SH}-\mathrm{U}$ at each time interval. Moreover, the runoff rate in $\mathrm{SH}-\mathrm{U}$ was far higher than the other two plant positions at each time interval, which re-confirmed that SH-L was the best one to conserve water and reduce surface runoff, followed by SH-M and SH-U. Specifically, runoff rate under SH$\mathrm{U}$ increased sharply from $0.083 \mathrm{~L} / \mathrm{min}$ to $0.217 \mathrm{~L} / \mathrm{min}$ at the first 9 min after runoff start-up, and then kept at a relatively stable level with an average rate of $0.224 \mathrm{~L} / \mathrm{min}$. At the same time, the runoff peak rate under $\mathrm{SH}-\mathrm{U}$ was captured in the 33rd minute after runoff generation, with a value of $0.246 \mathrm{~L} / \mathrm{min}$. The runoff rate at SH-M, however, sharply increased from $0.103 \mathrm{~L} / \mathrm{min}$ to $0.110 \mathrm{~L} / \mathrm{min}$ within the first $6 \mathrm{~min}$, and gently reached the $0.115 \mathrm{~L} / \mathrm{min}$ peak value, then declined a little bit with a mean value of $0.108 \mathrm{~L} / \mathrm{min}$ in the remaining time. Interestingly, the curve of the runoff rate under SH-L changed very slowly and gently throughout the whole process, and no rapid increasing trend was detected, especially in the first several minutes after runoff was generated. It started with a mean rate of $0.027 \mathrm{~L} / \mathrm{min}$ in the first $3 \mathrm{~min}$ after runoff starting, and slowly reached the peak rate of $0.087 \mathrm{~L} / \mathrm{min} 42 \mathrm{~min}$ later. This result showed that SH-L had a far stronger ability for reducing the sensitivity of runoff to rainfall than SH-M and SH-U.

\section{Discussions}

\subsection{Effects of changes in rainfall intensity on surface runoff}

In this study, the two types of rainfall intensities can be seen to represent moderate rainfalls and heavy rainstorms in the local region based on former research and historical records, which may induce severe overland flow and water erosion problems in most cases (Wei et al., 2007, 2009). In general, our study confirmed that high-intensity rainfalls (HIRs), rather than low-intensity rainfalls (LIRs), are generally prone to quicker responses of runoff generation under similar conditions of underlying surface. For example, the mean value of time to runoff under HIRs was $191.8 \mathrm{~s}$, which only accounted for $30 \%$ of that under LIRs (Table 2). This average value of time to runoff under grass and shrub changed from $200.1 \mathrm{~s}$ to $413.8 \mathrm{~s}$ and from $220.8 \mathrm{~s}$ to $685.7 \mathrm{~s}$ when underlying surface encountered HIRs and LIRs, respectively (Fig. 3c). Time to runoff under SH-U and SH-M was much higher than that of grass and shrub, but it still observed the decreasing order of LIRs and HIRs. Namely, runoff was more difficult to generate and be delayed under LIRs. No runoff loss was recorded in the SH-L covered plots under LIRs (Fig. 5c). Meanwhile, key indicators of water yield (e.g. runoff depth and total discharge), indicators of runoff-processes (mean flow and 

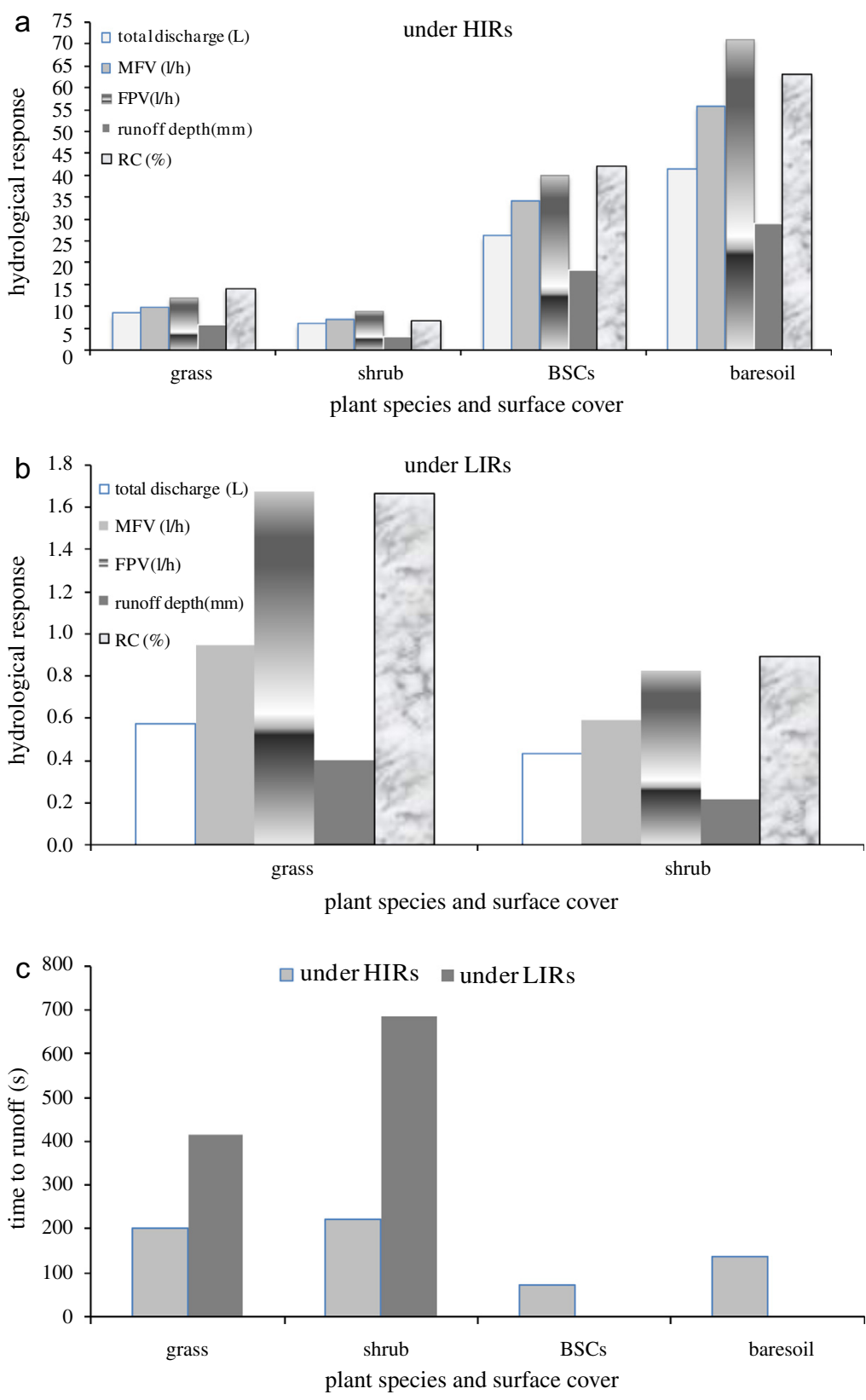

Fig. 4. Responses of runoff indicators to plant species and soil surface cover.

peak flow velocity) and indicators of runoff production ratio (RC) all confirmed that HIRs induced higher risk and consequences of peak flooding and surface water loss than those under LIRs. This indicates that rainstorms not only affect the specific dynamics of runoff, but also contribute to total water loss. More importantly, a threshold of rainfall inducing different runoff extents may exist, because the response between increases in rainfall variables and related runoff indicators was not parallel (Table 2). For example, an only 1.8 times an increase in rainfall intensity and $16 \%$ decrease in rainfall duration have caused a sharp increase in total discharge, runoff depth, mean flow velocity, peak flow velocity and runoff coefficient, with a value of $13.96,16.33,12.17,9.34$ and 9.23 times, respectively (Table 2).

This result may have important implications for the arid and semiarid ecosystems in the real world, especially when the region suffers accelerated rainfall variations in the context of climatic change (Weltzin et al., 2003). According to our former research in the same region, for example, the destructive effects of rainfall extremes on surface runoff generation exceeded 8 times that of ordinary rainfall pulses in the sloping farmlands (Wei et al., 2009). Increases in both rainfall intensity and total evapotranspiration may further aggregate the frangibility of the land surface, and increase the potential risks of runoff loss and the difficulties of vegetation rehabilitation (Richard, 2007; Wang et al., 2011; Putten et al., 2013). This phenomenon has been monitored to be a fact and predicted to be continued in many regions of the world (Sun et al., 2002). Small increases in the intensity and erosivity of rainfalls at large scales may induce severe peak flow and great loss of water resources in such regions, particularly in the poor surface covered and fragile ecosystems of the arid and semiarid regions (Zhao et al., 2009; Zhang and Liu, 2005). Such situations, however, will certainly increase the potential risk of 

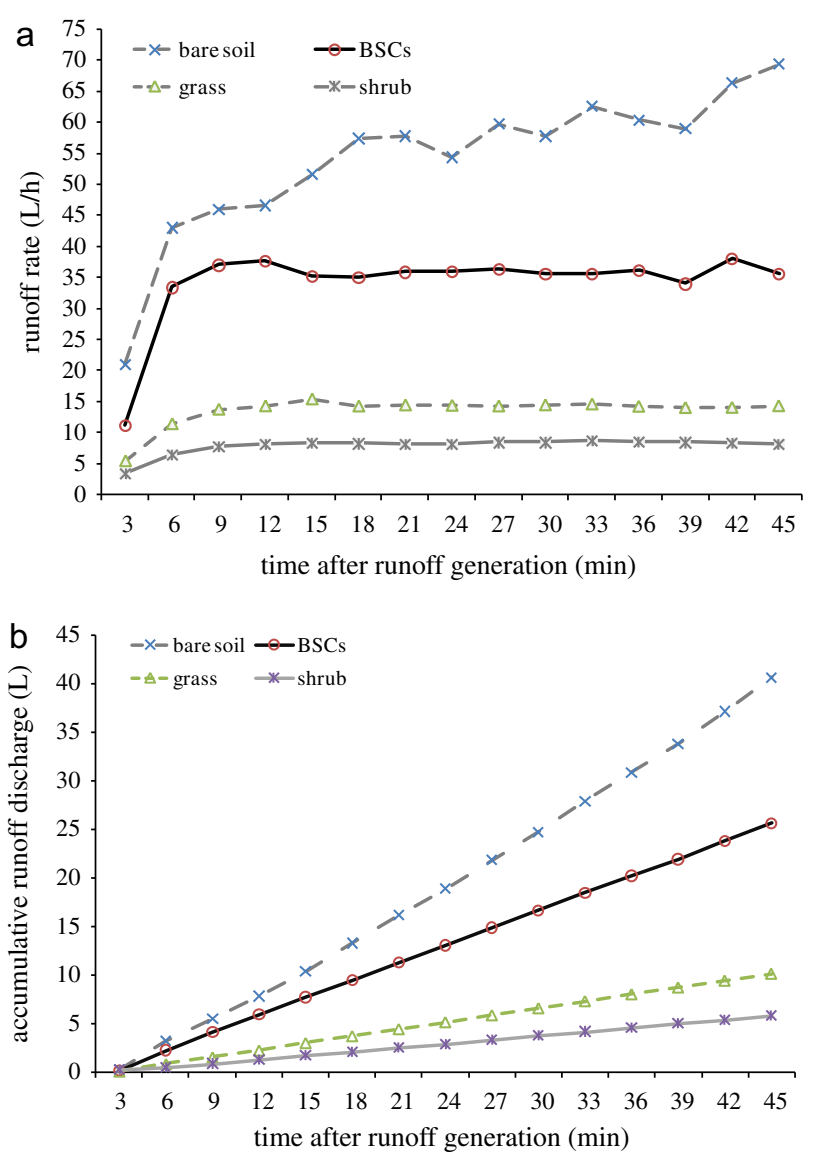

Fig. 5. Specific runoff processes under different plant species and surface cover at each time interval.

flooding, worsen the already stressed water conditions and eventually hamper ecological restoration processes.

\subsection{Effects of plant species and morphological features on surface runoff}

Our study indicates that the xerophytic seabuckthorn shrub and natural grass species act as more powerful tools in reducing water loss in sloping conditions than non-vegetated land surfaces, such as biological soil crusts (mainly dominated by moss) and bare soil conditions (Figs. 2 and 3). BSCs are much better than bare soil. Namely, shrub species in the plots can be considered as strong and effective landscape sink for retaining runoff and reducing surface water loss through overland flow, followed by grass species, then biological soil crusts. The risk of runoff generation under bare soil is highest. Several aspects may contribute to explaining the reasons for this phenomenon.

First, the difference of plant morphology between grass and shrub species is a crucial factor on raindrop interception and rainwater redistribution. Compared with grass and BSCs, shrub species have higher height, stronger woody stems, more developed branches and denser canopies (Xu et al., 2008; Table 1). Our field investigation during the growing season showed that the height and coverage of a single one-year-old seabuckthorn can reach $1.1 \mathrm{~m}$ and $73 \%$ respectively, which were far higher than those of grass species (Table 1). Local investigation in Dingxi also found that after 3-5 years of plant growth, the mean height, diameter at breast height (D.B.H.), crown width and ground diameter of seabuckthorn can reach $2.2 \mathrm{~m}, 2.8 \mathrm{~cm}, 1.8 \mathrm{~m}$ and $4.0 \mathrm{~cm}$, respectively (Unpublished data). Due to this reason, total rainwater captured by canopy interception and stemflow may help to reduce raindrop energy and total runoff depth (Meng et al., 2008; Návar, 2011; Yang et al., 2013). The Hortonian mechanism (rainfall excess infiltration) under such shrub species can be greatly weakened (Wei and Sun, 2009). For example, Li et al. (2008) found that stemflow under some shrubs (e.g. Reaumuria soongorica) in the Loess Plateau can reserve about $7.2 \%$ of the total gross precipitation, which becomes an important water source for soil moisture enhancement surrounded root systems and thus benefits plant survival. In turn, better plant growth can help to control runoff loss and improve soil conditions through root-network development and litter accumulation, which forms a virtuous cycle (Gyssels et al., 2005; Descheemaeker et al., 2006; Xu et al., 2009). Studies from other dry-land regions also draw similar conclusions (Wang et al., 2011; Xiao et al., 2011; Návar, 2011). Secondary natural grass (e.g. Common leymus and Solidleaf bluegrass), on the other hand, is better than BSCs in controlling runoff and water loss (Figs. 2 and 3). Such kinds of perennial herbage are suitable for the semiarid region and can grow well even in severely dry conditions. In this study, the role of BSCs in reducing runoff is far weaker than shrub and grass, but better than bare soil. Although the conclusions regarding the effect of BSCs on infiltration and runoff was inconsistent and even conflicted (Chamizo et al., 2012), our result clearly supports the opinion that BSCs can be considered as biological carpets to protect soil and save water in situ.

Second, different features of plant physiology can markedly affect runoff consequence. According to field investigation, seabuckthorn was found to have a powerful ability of tillering propagation, which induced a fast growing and quick spreading. A strong root system of seabuckthorn not only can ensure its survival rate under multiple pressures such as a rigorous climate and poor soil conditions, but it can also help to improve the properties of the soil surface (Gyssels et al., 2005; de Baets et al., 2007; Yang et al., 2013). This is believed to be an important means for rainwater infiltration enhancement and flood reduction (Jost et al., 2012; Tesfuhuney et al., 2013). Third, surface roughness among plant species differs. The surface roughness coefficient, which is popularly used in the hydrodynamics field, can reflect the buffering function of different underlying surfaces on runoff, to some extent. Changes in surface roughness may have a great influence on overland flow and water transport capacity (Montenegro et al., 2013). According to some studies, the coefficient of surface roughness decreased in the order of shrub, grass, BSCs and bare soil (Xiao et al., 2011). This changing trend is consistent with our findings (Fig. 3), confirming the best role of shrub in runoff control, followed by grass and BSCs. Last, different plant species may influence soil hydrological properties. For example, our former study in the same region also confirmed that seabuckthorn (shrub) and wheatgrass (natural grass) worked best for improving water holding capacity, litter depth accumulation and soil organic content, followed by alfalfa and Chinese pine, then spring wheat (Wei et al., 2009). Meanwhile, seabuckthorn can increase 1.7-5.5 times the soil organic matter and decrease soil buck density after 10 years of accumulation (Li et al., 2007). High SOM and low buck density, on the other hand, will increase soil aggregate stability and infiltration capacity, finally achieving the goal of water retention and runoff reduction (Xue et al., 2013).

\subsection{Effect of surface cover on runoff generation and process}

Our result indicated that the heterogeneity of effective surface cover may contribute to runoff differences. For instance, it is clear that bare soil has no effective protection compared to BSCs, grass and shrub. The effectiveness of BSCs cover is better than bare soil, but less than grass- and shrub-covered soil surface. In this study, it is interesting to ascertain the role of BSCs in surface hydrology. Being important components for sustaining ecological function in 

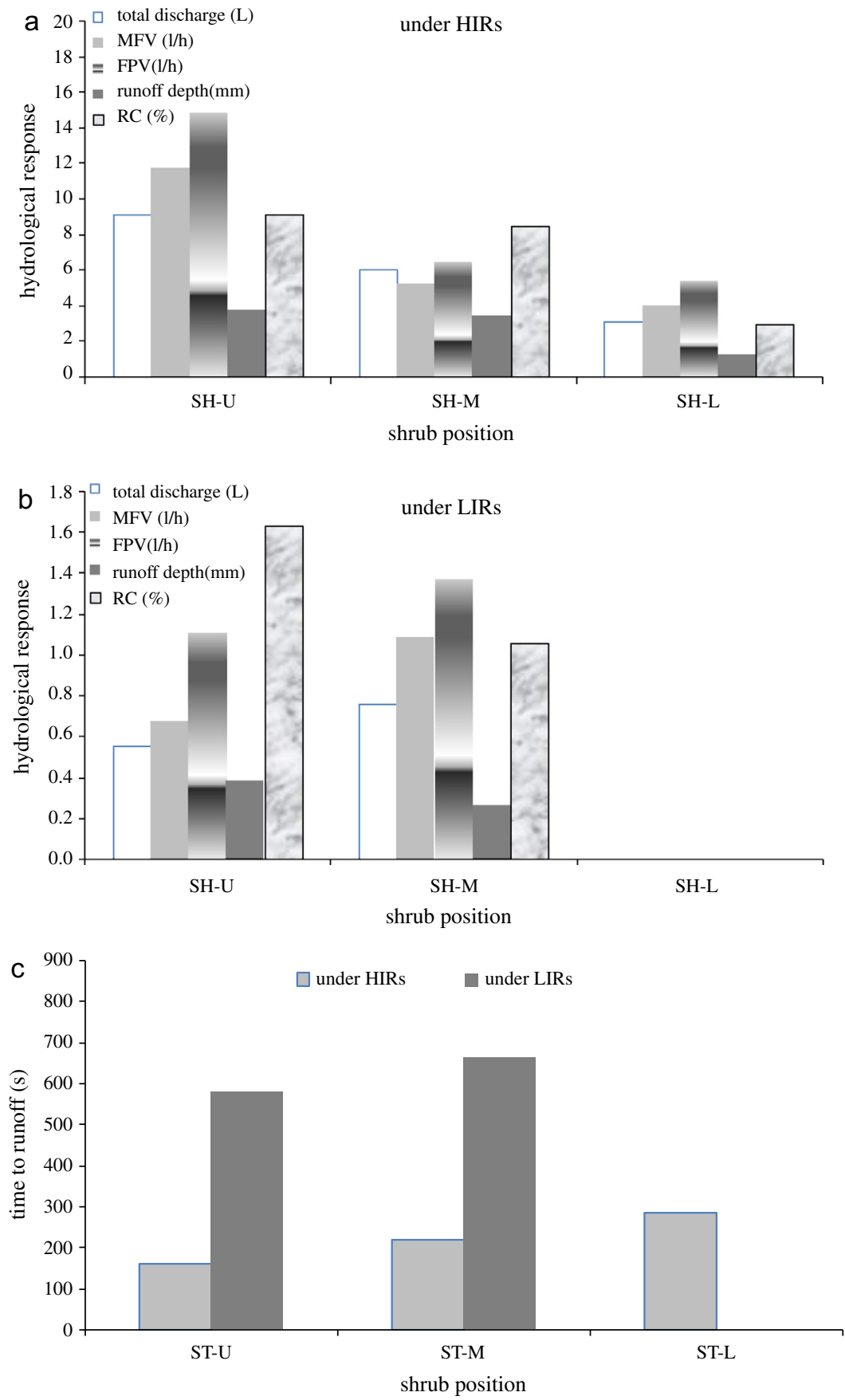

Fig. 6. Responses of runoff indicators to changes in shrub positions.

the arid and semiarid ecosystems (Chamizo et al., 2012), such microorganisms are widely distributed in the dry-land regions, including the Loess Plateau. Runoff velocity and water loss in bare soil were the highest, which is a strong source for runoff generation, and thus should be avoided in most cases. Other supplemental measures, such as mulching and land closure for natural vegetation succession are encouraged to be used in the field (Montenegro et al., 2013).

Meanwhile, field investigation indicated that the vertical protection of surface cover was very different across different plots (Table 1). For shrub covered plots, the underlying surface was protected not only by seabuckthorn, but also by grass and BSCs. Within such plots, the coverage of seabuckthorn was far higher than other plant species (Table 1). Grass covered plots were actually protected by the coupled role of grass species and BSCs communities. Although there was no shrub or grass protection in the BSCS covered plot, it was still far better than bare soil conditions. The total mean coverage of the plots also decreased in the order of shrub, grass, BSCs and bare soil, with a mean value of $77 \%, 69 \%$, $67 \%$ and $0 \%$ (Table 1 ), which contributed to the changes of runoff generation.

Many field experiments from different regions of the world also found that increased surface cover is an important measure for controlling water loss, improving soil environments, and altering surface hydrological processes and consequences (Durán Zuazo, 2004; Wei et al., 2007, 2009; Xu et al., 2008). The amount of soil cover or its effectiveness is also significant in reducing the velocity of overland flow (Imeson and Prinsen, 2004). For example, a 

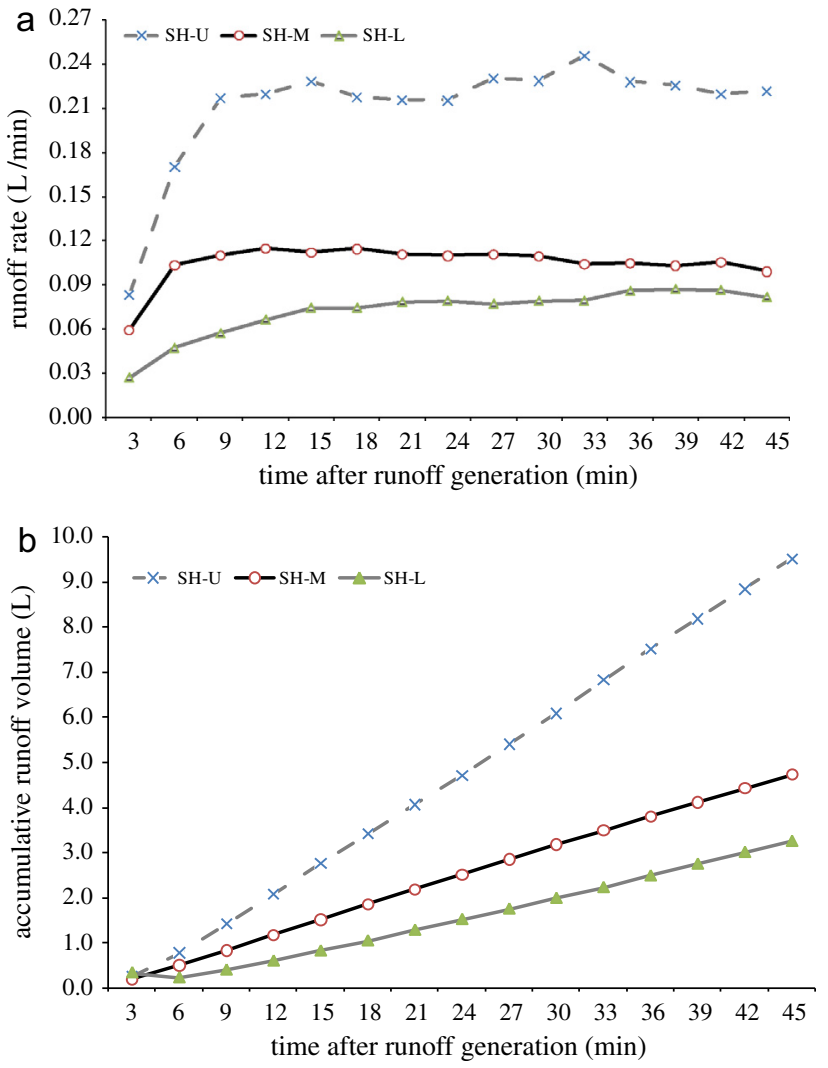

Fig. 7. Specific processes of runoff indicators to changes in shrub positions in the plots.

laboratory experiment conducted with rainfall simulation found that different mulches can protect surface soil effectively, increase rainwater infiltration and soil moisture content, decrease the threshold of runoff generation and delay the time to runoff at the same time (Montenegro et al., 2013). According to this result, mulch covers of $2 \mathrm{t} / \mathrm{ha}$ and $4 \mathrm{t} /$ ha caused reductions of $21 \%$ and $51 \%$ in the runoff peak, respectively (Montenegro et al., 2013). In the sub-tropical region of Florida, clear-cutting of a forest markedly increased the peak flow and total discharge, and made the groundwater level increase at least $100 \mathrm{~cm}$ (Sun et al., 2000). Meanwhile, most of the paired catchment studies around United States and European countries have indicated that deforestation will greatly remove the surface cover and reduce total evapotranspiration, thus increased flooding risk and total water loss (Scott and Lesch, 1997; Zhang et al., 2001; Robinson et al., 2003; Brown et al., 2005). In the state of Colorado, $40 \%$ removal of forest coverage increased $50-170 \%$ of total annual runoff, and increased the peak flooding in most years (Wei and Sun, 2009). The predatory destruction of vegetation during the growing season induced a flood crest increase of 15-60\% (Hornbeck et al., 1993). In the humid Coweeta watershed of Southern America, plant removal increased 7-30\% of peak flow (Bosch and Hewlett, 1982).

\subsection{Effects of vegetation spatial position on runoff yield and process}

Our study found that the specific position of shrub species in the experimental plots play a crucial role in affecting the process and consequence of runoff performance (Figs. 4 and 5). Shrub in the lower part of the plots (SH-L) was the best to control runoff, followed by shrub in the middle (SH-M) and shrub in the upper positions (SH-U). Meanwhile, our study also confirmed SH-L can be considered as the strongest sink of rainwater-runoff within the mentioned land surfaces. The difference of runoff consequence under SH-M and SH-U, on the other hand, was not significant. This result indicated that the buffering role of shrub in altering surface hydrology is greatly dominated by its specific position and spatial distribution.

As stressed before, understanding the placement of plant species across the hillslope and detecting how the related runoff dynamics reflect and respond to rainfall pulses is of great value for runoff source-sink transformation in the arid and semiarid ecosystems (Imeson and Prinsen, 2004). In our study, the function of single shrub position in the experimental plots seems similar to the role of so-called "vegetative filter strips" (VFS), "plant belts" or "biological buffer strips" (BBS) in reducing losses of surface water and nutrient materials (Ellis et al., 2006; Maetens et al., 2012; Ma et al., 2013). According to Borin et al. (2005), for example, the buffer strips (BS) of biological materials can reduce the total runoff amount by $78 \%$ compared to no-BS, mainly derived from the decreased flow hydraulics resulting from the increased soil infiltration and surface roughness. In semiarid South-eastern Australia, tree belts can reduce runoff loss by $32-68 \%$ in a one-in-tenyear rainstorm event and by $100 \%$ in a one-in-two-year storm event from a pastured hill-slope (Ellis et al., 2006), and the researchers attributed the reason of runoff reduction to the role of tree roots performing in increasing infiltration in the root and surface soil zones. In Mediterranean rangeland, trees planted in the grassland slopes were detected to increase water storage beneath their canopy and reduce erosion as well as surface water runoff (Joffre and Rambal, 1993). Liu et al. (2013) also declared that protective measures worked best when located at the lowest position along slopes. According to our field investigation shown in Table 1 , the surface coverage of SH-U, SH-M and SH-L was recorded as $73 \%, 88 \%$ and $72 \%$, respectively. Meanwhile, the height of a single species of seabuckthorn in SH-U, SH-M and SH-L was $87 \mathrm{~cm}$, $112 \mathrm{~cm}$ and $86 \mathrm{~cm}$ respectively, with the related surface coverage being $41 \%, 73 \%$ and $45 \%$, respectively (Table 1 ). This showed that, although the coverage of single shrub and total plant community in the SH-L plot was not higher (sometimes even lower) than SH$\mathrm{U}$ and SH-M, the related runoff loss under SH-L was still the lowest. Consequently, this result reconfirmed the importance of plant position buffers in reducing surface runoff generation and flooding risk in practice in dry-land ecosystems.

\section{Conclusions and implications}

In this study, micro-plot rainfall simulations were implemented to detect how runoff responds to various plant species, surface cover and vegetation distribution under high or low intensity rainfalls in a semiarid loess hilly area in China. Several major interesting findings were discovered. Firstly, runoff response was generally more sensitive to HIRs than LIRs under similar underlying surfaces. According to our simulations, a 1.8 times increase in rainfall intensity can induce many-folds (9-16 times, for example) of increases in peak flooding discharge and severe water loss. Changes in rainfall variables and the responses of key runoff indicators are not equal or coordinate. Secondly, the effects of different plant species and surface cover on runoff differed significantly. Seabuckthorn, being a suitable shrub species in the semiarid area, was proved to be more powerful for reducing flooding rates and retaining water loss, and delayed the time to runoff significantly, followed by secondary natural grass and biological soil crusts (BSCs). Bare soil is the worst, which can be attributed to the strong source of surface runoff generation and water loss, mainly due to no effective surface cover. Thirdly, the spatial position and distribution of plants play crucial roles in affecting runoff dynamics. Shrub at 
lower position (SH-L) has the most powerful buffering role in minimizing runoff loss, followed by SH-M, then SH-U.

Our findings have important implications for overland flow reduction, water conservation and ecological restoration in the arid and semiarid ecosystems. Three highlighted inspirations, which may benefit surface runoff control in practice, are stressed here. First, small increases in rainfall intensity may induce severe flooding disasters and great losses of water resources based on our results. Special attention, therefore, should be paid to the spatiotemporal pattern of natural stochastic rainfall (e.g. extreme rainfall events) in the real world, and valid measures should be taken to prevent its destructive effects, which may possibly bring nature to society, especially in the context of accelerated climatic change. Second, suitable plant species should be carefully selected and planted in terms of the sloping conditions for runoff reduction and ecological rehabilitation. Such plant selection measures must depend upon scientific field experimental studies. Shrub plantations were suggested as good choices in practice, while natural grasses and BSCs should be protected to develop well under the shrub canopies. Bare soil conditions, being strong runoff sources, should be avoided at full stretch through complicated management such as artificial plantation, surface mulching or land closure for natural succession. Third, since the specific positions of plants play effective roles in regulating water yield and hydrological processes, higher attention should be paid to the spatial distribution and landscape structure of vegetation on the slopes. The powerful buffer of shrub in the lower position of the hill-slope should be taken into consideration, particularly when an ecological and landscape design project is conducted in the loess hilly area and other fragile mountainous regions. Namely, the importance of vegetation pattern design should be emphasized and implemented scientifically in ecological restoration practices.

\section{Acknowledgements}

The Dingxi Institute of Soil and Water Conservation in Gansu province and several anonymous farmers are acknowledged for their warm-hearted assistance in plots construction, rainfall simulation and field cooperation. This research was supported by the National Natural Science Foundation of China (Nos. 41390462, 41371123).

\section{References}

Abudi, I., Carmi, G., Berliner, P., 2012. Rainfall simulator for field runoff studies. J. Hydrol. 454-455, 76-81.

Bochet, E., Rubio, J.L., Poesen, J., 1998. Relative efficiency of three representative matorral species in reducing water erosion at the microscale in a semiarid climate (Valenicia, Spain). Geomorphology 23, 139-150.

Borin, M., Vianello, M., Morari, F., Zanin, G., 2005. Effectiveness of buffer strips in removing pollutants in runoff from a cultivated field in North-East Italy. Agric. Ecosyst. Environ. 105, 101-114.

Bosch, J.M., Hewlett, J.D., 1982. A review of catchment experiments to determine the effect of vegetation changes on water yield and evapotranspiration. J. Hydrol. 55, 23-33.

Brown, A.E., Zhang, L., McMahon, T.A., Western, A.W., Vertessy, R.A., 2005. A review of paired catchment studies for determining changes in water yield resulting from alterations in vegetation. J. Hydrol. 310, 28-61.

Cantón, Y., Solé-Benet, A., de Vente, J., Boix-Fayos, C., Calvo-Cases, A., Asensio, C., Puigdefábregas, J., 2011. A review of runoff generation and soil erosion across scales in semiarid South-eastern Spain. J. Arid Environ. 75, 1254-1261.

Cerdà, A., 1998. Effect of climate on surface flow along a climatological gradient in Israel: a field rainfall simulation approach. J. Arid Environ. 38, 145-159.

Chamizo, S., Cantón, Y., Rodríguez-Caballero, E., Domingo, F., Escudero, A., 2012 Runoff at contrasting scales in a semiarid ecosystem: a complex balance between biological soil crust features and rainfall characteristics. J. Hydrol. 452-453, 130-138.

Chen, L.D., Huang, Z.L., Gong, J., Fu, B.J., Huang, Y.L., 2007. The effect of land cover/ vegetation on soil water dynamic in the hilly area of the loess plateau, China. Catena 70 (2), 200-208. de Baets, S., Poesen, J., Knapen, A., Barbera, G.G., Navarro, J.A., 2007. Root characteristics of representative Mediterranean plant species and their erosion reducing potential during concentrated runoff. Plant Soil 294, 169-183. Descheemaeker, K., Muys, B., Nyssen, J., Poesen, J., Raes, D., Haile, M., Deckers, J., 2006. Litter production and organic matter accumulation in exclosures of the Tigray highlands, Ethiopia. Forest Ecol. Manage. 233 (1), 21-35.

Durán Zuazo, V.H., 2004. Impact of vegetation cover on runoff and soil erosion at hillslope scale in Lanjaron, Spain. Environmentalist 24, 39-48.

Ellis, T.W., Leguédois, S., Hairsine, P.B., Tongway, D.J., 2006. Capture of overland flow by a tree belt on a pastured hillslope in South-eastern Australia. Aust. J. Soil Res. 44, 117-125.

FAO-UNESCO, 1974. Soil Map of the World (1:5000 000). Food and agriculture organization of the United Nations, UNESCO, Paris.

Gyssels, G., Poesen, J., Bochet, E., Li, Y., 2005. Impact of plant roots on the resistance of soils to erosion by water: a review. Prog. Phys. Geogr. 29 (2), 189-217.

Hornbeck, J.W., Adams, M.B., Corbett, E.S., Verry, E.S., Lynch, J.A., 1993. Long-term impacts of forest treatments on water yield: a summary for northeastern USA. J. Hydrol. 150 (2-4), 323-344.

Huang, J., Wu, P.T., Zhao, X.N., 2013. Effects of rainfall intensity, underlying surface and slope gradient on soil infiltration under simulated rainfall experiments. Catena 104, 93-102.

Imeson, A.C., Prinsen, H.A.M., 2004. Vegetation patterns as biological indicators for identifying runoff and sediment source and sink areas for semiarid landscapes in Spain. Agric. Ecosyst. Environ. 104, 333-342.

Joffre, R., Rambal, S., 1993. How tree cover influences the water balance of Mediterranean Rangelands. Ecology 74, 570-582.

Jost, G., Schume, H., Hager, H., Markart, G., Kohl, B., 2012. A hillslope scale comparison of tree species influence on soil moisture dynamics and runoff processes during intense rainfall. J. Hydrol. 420-421, 112-124.

Li, H.E., Li, G.J., Zhang, K., Zhang, T., Li, G., 2007. Research on the effect of seabuckthorn flexible dam on the improvement of soil organic matter. Bull. Soil Water Conservation 12 (6), 1-4 (in Chinese).

Li, X.Y., Liu, L.Y., Gao, S.Y., Ma, Y.J., Yang, Z.P., 2008. Stemflow in three shrubs and its effect on soil water enhancement in semiarid loess region of China. Agric. Forest Meteorology 148, 1501-1507.

Li, Z., Liu, W.B., Zhang, X.C., Zheng, F.L., 2009. Impacts of land use change and climate variability on hydrology in an agricultural catchment on the Loess Plateau of China. J. Hydrol. 377, 35-42.

Liu, S.L., Dong, Y.H., Li, D., Liu, Q., Wang, J., Zhang, X.L., 2013. Effects of different terrace protection measures in a sloping land consolidation project targeting soil erosion at the slope scale. Ecol. Eng. 53, 46-53.

Luk, S., Abrahams, A.D., Parsons, A.J., 1986. A simple rainfall simulator and trickle system for hydro-geo-morphical experiments. Phys. Geogr. 7, 344-356.

Ma, L., Pan, C.Z., Teng, Y.G., Shangguan, Z.P., 2013. The performance of grass filter strips in controlling high-concentration suspended sediment from overland flow under rainfall/non-rainfall conditions. Earth Surf. Proc. Land. 38, 15231534.

Maetens, W., Poesen, J., Vanmaercke, M., 2012. How effective are soil conservation techniques in reducing plot runoff and soil loss in Europe and the Mediterranean? Earth Sci. Rev. 115, 21-36.

Mayor, Á.G., Bautista, S., Bellot, J., 2011. Scale-dependent variation in runoff and sediment yield in a semiarid mediterranean catchment. J. Hydrol. 397 (1-2), $128-135$.

Meng, Q.H., Fu, B.J., Tang, X.p., Ren, H.C., 2008. Effects of land use on phosphorous loss in the hilly area of the Loess Plateau, China. Environ. Monit. Assess. 139, 195-204.

Montenegro, A., Abrantes, J., de Lima, J., Singh, V., Santos, T., 2013. Impact of mulching on soil and water dynamics under intermittent simulated rainfall. Catena 109, 139-149.

Návar, J., 2011. Stemflow variation in Mexico's northeastern forest communities: its contribution to soil moisture content and aquifer recharge. J. Hydrol. 408, 3542.

Pérez-Latorre, F., de Castro, L., Delgado, A., 2010. A comparison of two variable intensity rainfall simulators for runoff studies. Soil Tillage Res. 107, 11-16.

Putten, W.H.V.D., Bardgett, R.D., Bever, J.D., Bezemer, T.M., et al., 2013. Plant-soil feedbacks: the past, the present and future challenges. J. Ecol. 101, 265276.

Richard, A.K., 2007. Global warming is changing the world. Science 316, 188-190.

Robinson, M., Cognard-Plancq, A.L., Cosandey, C., et al., 2003. Studies of the impact of forests on peak flows and baseflows: a European perspective. Forest Ecol. Manage. 186, 85-97.

Rodríguez-Caballero, E., Cantón, Y., Chamizo, S., Afana, A., Solé-Benet, A., 2012. Effects of biological soil crusts on surface roughness and implications for runoff and erosion. Geomorphology 145-146, 81-89.

Scott, D.F., Lesch, W., 1997. Streamflow responses to afforestation with Eucalyptus grandis and Pinus patula and to felling in the Mokobulaan experimental catchments, South Africa. J. Hydrol. 199, 360-377.

Shi, Z.H., Yan, F.L., Li, L., Li, Z.X., Cai, C.F., 2010. Interrill erosion from disturbed and undisturbed samples in relation to topsoil aggregate stability in red soils fromsubtropical China. Catena 81, 240-248.

Shi, Z.H., Fang, N.F., Wu, F.Z., Wang, L., Yue, B.J., Wu, G.L., 2012. Soil erosion processes and sediment sorting associated with transport mechanisms on steep slopes. J. Hydrol., 123-130.

Shi, Z.H., Yue, B.J., Wang, L., Fang, N.F., Wang, D., Wu, F.Z., 2013. Effects of mulch cover rate on interrill erosion processes and the size selectivity of eroded sediment on steep slopes. Soil Sci. Soc. Am. J. 77, 257-267. 
Sinoga, J., Diaz, A., Bueno, E., Murillo, J.F., 2010. The role of soil surface conditions in regulating runoff and erosion processes on a metamorphic hillslope (Southern Spain). Catena 80, 131-139.

Sun, G., Riekerk, H., Comerford, N.B., 2000. Groundwater table rise after forest harvesting on cypress-pine flatwoods in Florida. Wetlands 20 (1), 101-112.

Sun, G., McNulty, S.G., Moore, J., Bunch, C., Ni, J., 2002. Potential impacts of climate change on rainfall erosivity and water availability in China in the next 100 years. In: Proceedings of the 12 th international soil conservation conference. Beijing, China.

Tesfuhuney, W.A., Van Rensburg, L.D., Walker, S., 2013. In-field runoff as affected by runoff strip length and mulch cover. Soil Tillage Res. 131, 47-54.

Wang, L., Wei, S.P., Horton, R., Shao, M.A., 2011. Effects of vegetation and slope aspect on water budget in the hill and gully region of the Loess Plateau of China. Catena 87, 90-100.

Wei, X.H., Sun, G., 2009. Watershed Ecosystem Processes and Management. Higher Education Press, pp. 1-419. (in Chinese).

Wei, W., Chen, L.D., Fu, B.J., Huang, Z.L., Wu, D.P., Gui, L.D., 2007. The effect of land use and rainfall regimes on runoff and erosion in the loess hilly area, China. J. Hydrol. 335 (3-4), 247-258.

Wei, W., Chen, L.D., Fu, B.J., Lü, Y.H., Gong, J., 2009. Responses of water erosion to rainfall extremes and vegetation types in a loess semiarid hilly area, NW China. Hydrol. Process. 23, 1780-1791.

Weltzin, J.F., Loik, M.E., Schwinning, S., Williams, D.G., Fay, P.A., 2003. Assessing the response of terrestrial ecosystems to potential changes in precipitation. Bioscience 53 (10), 941-952.
Xiao, P.Q., Yao, W.Y., Römkens, M.J.M., 2011. Effects of grass and shrub cover on the critical unit stream power in overland flow. Inter. J. Sed. Res. 26, 387-394.

Xu, X.L., Ma, K.M., Fu, B.J., Song, C.J., Liu, W., 2008. Influence of three plant species with different morphologies on water runoff and soil loss in a dry-warm river valley, SW China. For. Ecol. Manage. 256, 656-663.

Xu, X.L., Ma, K.M., Fu, B.J., Liu, W., Song, C.J., 2009. Soil and water erosion under different plant species in a semiarid river valley, SW China: the effects of plant morphology. Ecol. Res. 24, 37-46.

Xue, Z.J., Man, C., An, S.S., 2013. Soil nitrogen distributions for different land uses and landscape positions in a small watershed on Loess Plateau, China. Ecol. Eng. 60, 204-213.

Yang, L., Wei, W., Chen, L.D., Mo, B.R.,2012. Response of deep soil moisture to land use and afforestation in the semi-arid Loess Plateau, China. J. Hydrol. 475, 111 122.

Yang, F.S., Cao, M.M., Li, H.E., Wang, X.H., Bi, C.F., 2013. Simulation of sediment retention effects of the single seabuckthorn flexible dam in the Pisha Sandstone area. Ecol. Eng. 52, 228-237.

Zhang, X.C., Liu, W.Z., 2005. Simulating potential response of hydrology, soil erosion, and crop productivity to climate change in Changwu tableland region on the Loess Plateau of China. Agric. For. Meteorol. 131, 127-142.

Zhang, L., Dawes, W.R., Walker, G.R., 2001. Response of mean annual evapotranspiration to vegetation changes at catchment scale. Water Resour Res. 37, 701-708.

Zhao, F., Deng, H., Zhao, X., 2009. Rainfall regime in three Gorges area in China and the control factors. Int. J. Climatol. 30, 1396-1406. 